\title{
Geological setting of the Païolive karst (Ardèche, South of France): Consequences on its genesis and vertical development.
}

Céline Baral ${ }^{1}$, Michel Séranne ${ }^{1}$, Séverin Pistre ${ }^{2}$

${ }^{1}$ : Géosciences Montpellier, CNRS-Université de Montpellier-Université de Guadeloupe michel.seranne@umontpellier.fr

${ }^{2}$ : Hydrosciences Montpellier, CNRS-IRD-Université de Montpellier

Keywords: karst, incision, paleo-surface, base-level, geomorphology

Paper published in 2019 in C. Bertrand et al. (eds.), Eurokarst 2018, Besançon, Advances in Karst Science, https://doi.org/10.1007/978-3-030-14015-1_5

\begin{abstract}
A combined geological-geomorphological analysis of the Païolive area, Ardèche, southern France, allows to discuss the extension, origin and chronology of the karst that affects late Jurassic limestone. Results point to paleo-surface abandonment, river incision and karst formation resulting from a late Miocene and pre-Messinian uplift of the area. The epigene karst does not extend below the present-day base-level.
\end{abstract}

\section{Introduction}

Intensely karstified landscapes of Ardèche (southern France) attract many tourists, rising seasonal problems of water supply. Underground water resources, especially karstic reservoirs, provide most of the supply for the region, such as the Païolive karst, located between the Chassezac and La Baume rivers. This karst constitutes a strategic aquifer of this area, however its geometry and vertical development are poorly known.

This preliminary study of the geological setting of the Païolive karst (Fig. 1a, 1b) aims at testing a combined geological and geomorphological approach, in order to document the karst extension and to improve the understanding of its formation. This will, in turn, bring important constraints on its hydrological modeling with water resource objectives, which is not the scope of this contribution. Although karsts related to the incision of the Mesozoic carbonate platform by the Ardèche river (Ardèche canyon, Fig. 1a) have been analyzed (e.g. (Mocochain et al., 2006a; Mocochain et al., 2006b; Tassy et al., 2013), karsts of the upper reaches of the area, along the Cevennes margin, are much less investigated (Bakalowicz, 2008). The proximity of both areas, could argue for a common origin of their respective karst networks, however, our results point to significant differences in the genesis of rivers and karst incisions, as well as an original development of the Païolive karst. 

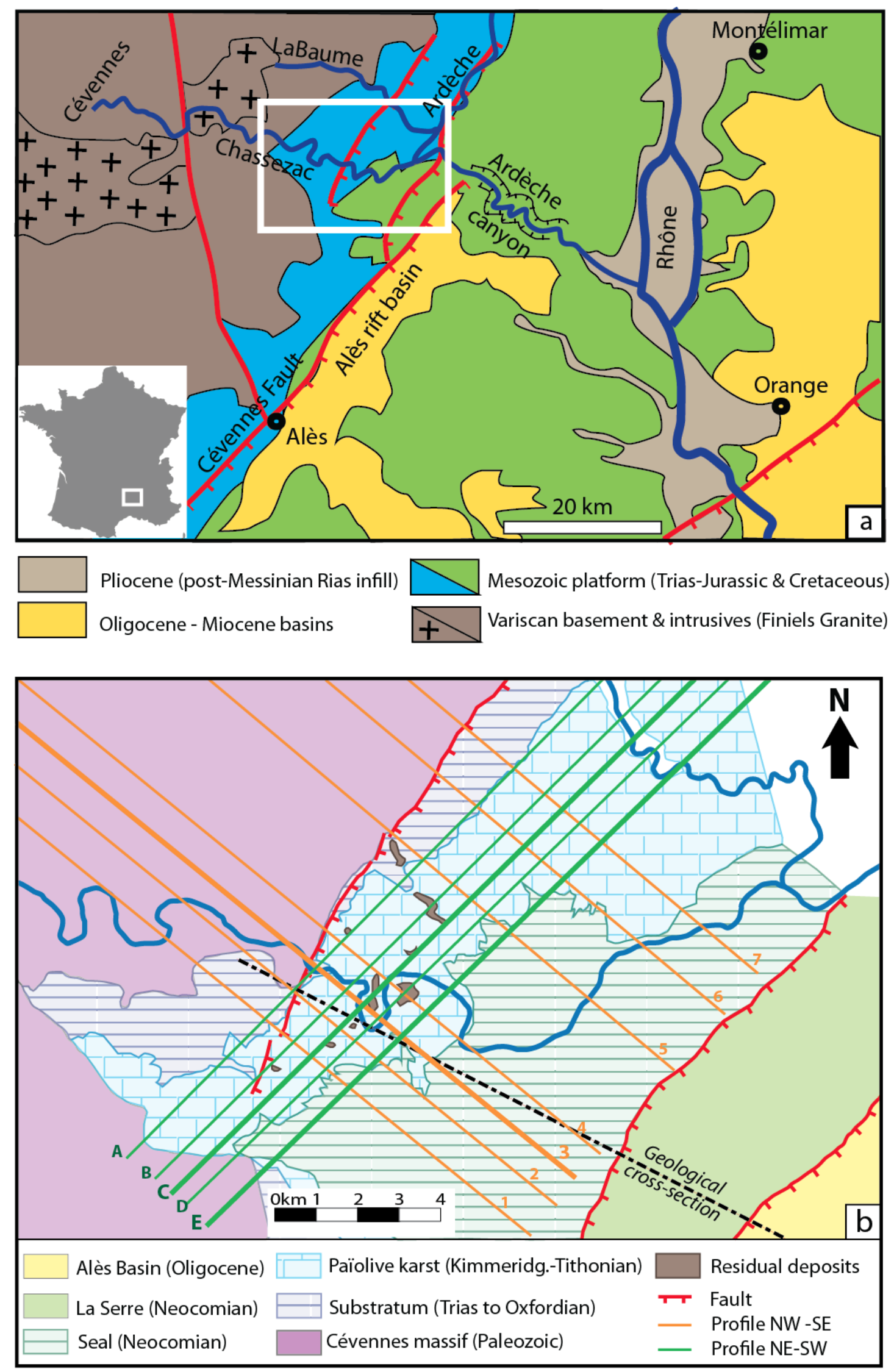

Fig. 1a : Geological setting of the study area (white frame); $1 \boldsymbol{b}$ : Geological map showing the structure of the Païolive aquifer (substratum, karstic aquifer, seal) and localizing residual deposits. Locations of the geological cross-section (Fig. 2) and of all analyzed elevation profiles are indicated; bold lines indicate the profiles shown in this contribution (Fig. $3 \& 4$ ). 
We first analyse the structural framework and geological cross-sections, in order to localize the karstic massif in relation with the tectonic structures resulting from regional geodynamics. Lithostratigraphic analysis is used to distinguish reservoirs and seals formations, and to date some geodynamic events, crucial for the karst formation. Then, geomorphological analyses of Païolive and surrounding areas, correlated with sedimentological observations of residual deposits, leads to i) identify paleo-surfaces and their subsequent deformations; ii) determine the upstream sources iii) constrain the downstream position of each paleosurface. Finally, the numerous available speleological data (Chabaud and Lhomme, 2016) are plotted with respect to the paleo-surfaces and present-day base-level, and analysed as first order approximation of the karst vertical development.

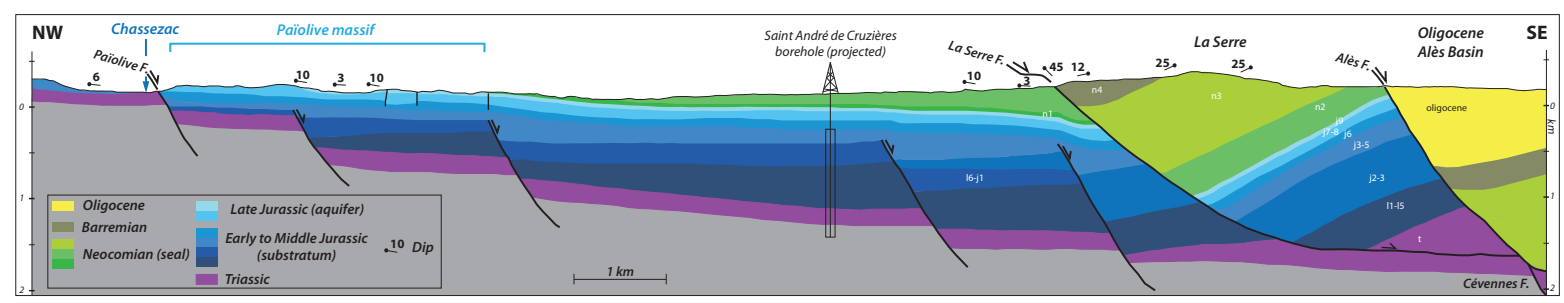

Fig. 1 : Geological cross-section of the studied area locating the karstic massif in relation with the tectonic structures. Note that Late Jurassic to Early Cretaceous formations are slightly dipping SE, and that Neocomian was overlying Jurassic-Early Cretaceous limestones.

\section{Lithostratigraphy and structural analyses}

The Païolive karstic aquifer develops in Late Jurassic (Kimmeridgian-Tithonian) to Early Cretaceous (Berriasian) limestones. It rests on Early to Middle Jurassic alternating marls and marly limestones which constitute the aquifer substratum. It is covered and sealed by Valanginian marls and limestones (Elmi et al., 1989).

Earlier structural studies across the Ardèche margin, along strike $15 \mathrm{~km}$ further north (Bonijoly et al., 1996) and several exploration borehole data, provide the base for the geological cross-section (Fig. 2). It shows that Late Jurassic to Early Cretaceous formations are slightly dipping SE. These are affected by low amplitude anticline flexures oriented NESW, responding to a post-deposition reactivation of basement faults (Séguret et al., 1997). To the southeast, the studied reservoir is sealed at depth against the Hauterivian marly formation, across a listric fault bounding the tilted block of la Serre. This fault is a splay of the Cevennes fault reactivated as an extensional fault during the Oligocene rifting and formation of the Alès rift basin (Fig. 1a) (Sanchis and Séranne, 2000). Structural and stratigraphic restoration of the Neocomian formation (the marly seal) indicates that it was overlying and thus, preserving Jurassic-Early Cretaceous limestones from epigene karstification, prior to its erosional denudation.

\section{Geomorphology}

We use the base-level concept as defined by (Wheeler, 1964); it is a theoretical, dynamic surface, which undulates around the topographic surface and is linked downstream to a still water surface (lake or sea). Where and when base-level surface is below topography, rocks 
located between the two surfaces are unstable and prone to erosion, weathering or karstification. Where and when base-level surface lies above topography, sediments may be deposited and preserved. Where and when the two surfaces meet, there is neither erosion nor deposition: it corresponds to sediment bypass. As a first-order approximation, base-level surface can therefore be correlated with a steady-state, physical, topographic surface, which combines erosional, by-pass and depositional surfaces. Epigene karst formation depends on base-level variations in space and time and occurs when base-level drops below topography, leading to carbonate dissolution in limestone areas. Base level drop also leads to river network incision and abandonment of surfaces, which may be covered with residual fluvial sediments. Such paleo-surfaces can be interpolated across present-day landscape, and they characterize paleo-base-levels. In cross-sections, base-level surface can be assigned to an upstream downstream profile. The methodology is based on the analysis of such profiles extracted from GoogleEarth application, and displayed with a highly exaggerated vertical scale. This implies that only variations (not the values) of slopes are relevant in the analysis. Profiles display concave upward segments topping relative highs, which can be correlated downstream in a consistent way as an almost asymptotic curve, and interpreted as sections across paleosurfaces. We have investigated 5 parallel elevations profiles trending NE-SW and 7 profiles trending NW-SE, Figure 3 and 4 represent three of such orthogonal profiles. Geology and occurrence of residual sediments are plotted on the profiles, in order to map the paleo-surface.

The present-day base-level is plotted as the surface interpolated between local topographic lows, such as the intersection of the elevation profile with the Chassezac and La Baume rivers, and it is compared with the paleo-surface. Smaller extension, linear, fluvial terraces found close to present-day river network, have not been distinguished from present-day baselevel. The entrance elevation and vertical development of karst cavities (Chabaud and Lhomme, 2016) are also plotted on the profiles.

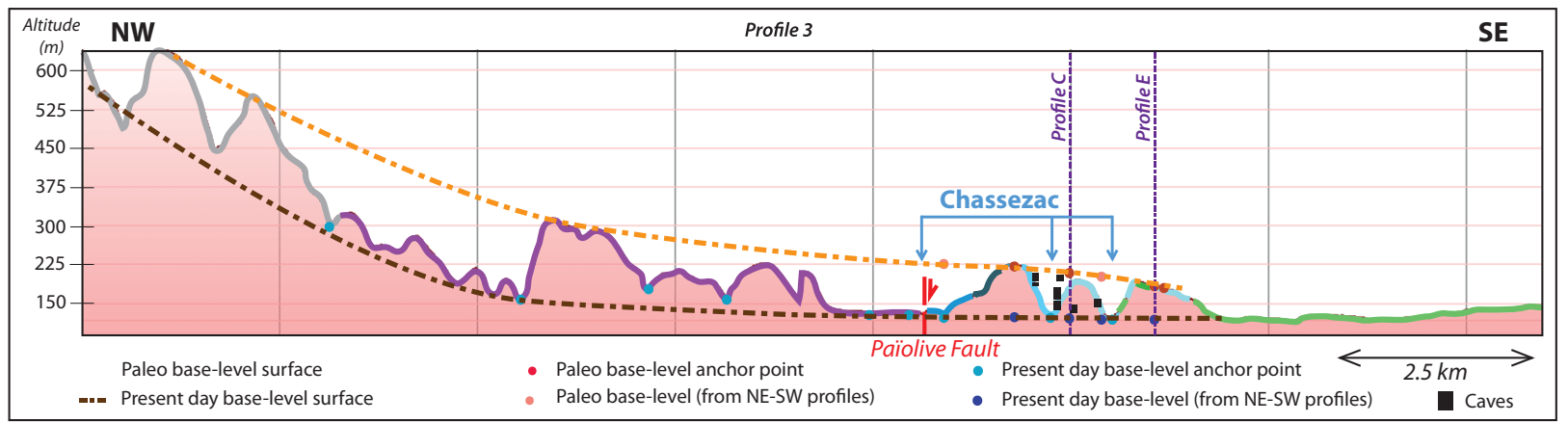

Fig. 3 : Elevation profile trending NW-SE showing the interpreted paleo- and present day base-level surfaces. The colors on the topographic surface show the lithologies with the same code as in the geological cross-section (Fig. 2). In section, the paleo-surface shows an concave upward upstream-downstream profile with an upstream in the Cévennes Paleozoic basement.

A distinctive paleo-surface intersects different lithologies (Fig. 3): its upstream lies in the Cévennes Paleozoic basement and it cuts the gently SE-dipping monocline of Triassic to Valanginian sequences, while downstream it is located against the tilted block of la Serre, which forced the river to flow northeastward, i.e. normal to the section. This paleo-surface presents an almost asymptotic profile as seen in a NW-SE-section, while it displays a corrugated geometry across orthogonal profiles, with a succession of SE-trending ridges and gullies (Fig. 4). Paleo-valleys are characterized by the presence of residual sediments 
deposited in the gullies, which are mapped across the study area (Elmi et al., 1989), as well as south of it (Clerc, 2009). In the Païolive karst, detrital elements include allochthonous pebbles and boulders of quartz, schists, hematite lateritic crust fragments and distinctive granites boulders that can be correlated with the late Variscan intrusive (Fig. 1a). Detrital allochthonous sediments indicate the source and confirm the presence of a paleo-Chassezac river, which drained the Paleozoic Cevennes basement, including late Variscan granite exposed in the watershed.

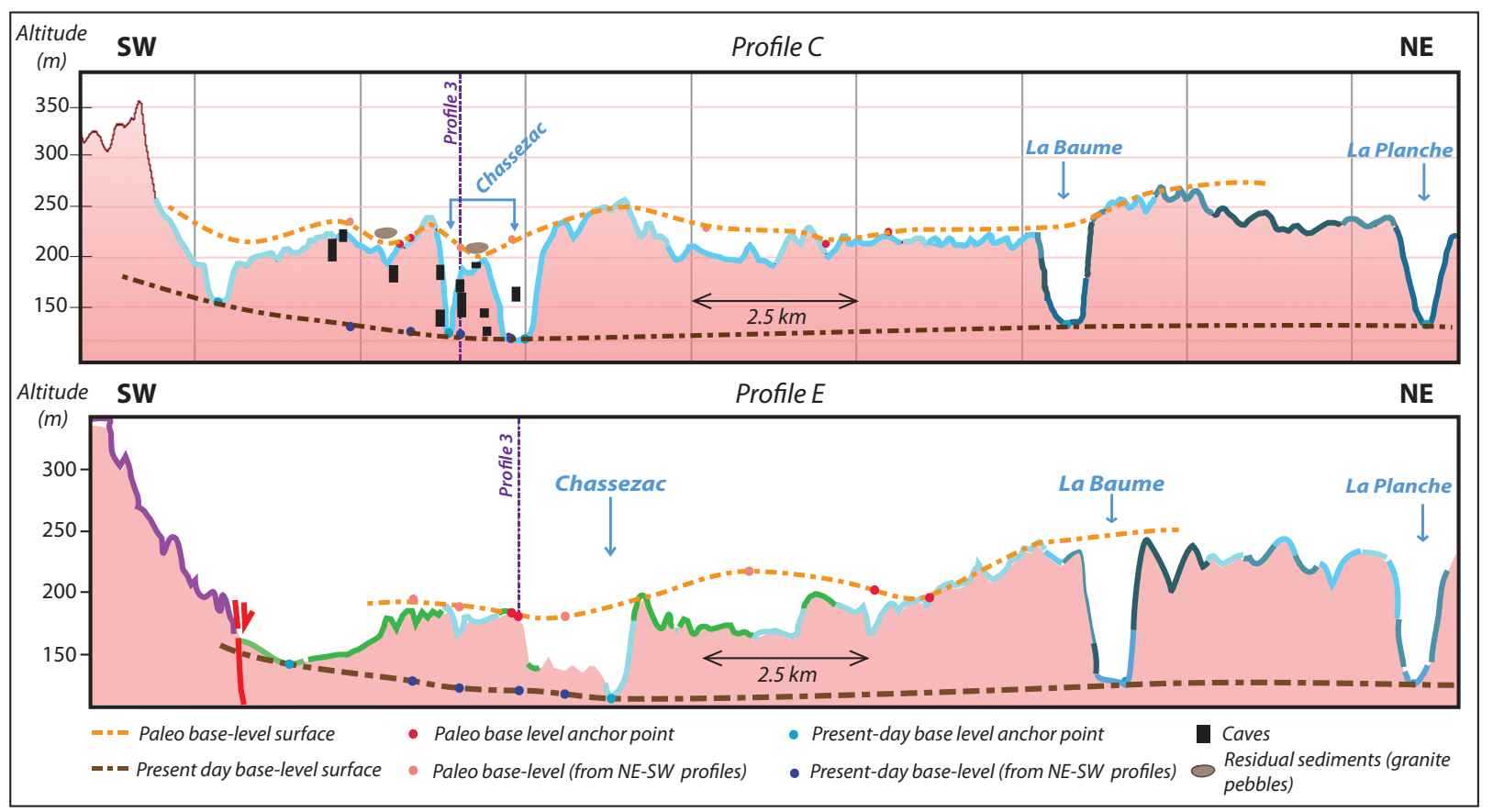

Fig. 4: Elevation profiles trending SW-NE showing the interpretation of paleo- and presentday base-level surface. The colors on the topographic surface show the lithologies with the same code as in the geological cross-section. Note the SE-trending ridges and gullies affected by the paleo-surface. The residual sediments are located in the gullies, i.e. the paleo-valleys. Anchor points (red dots) correspond to occurrences of residual sediments found on the paleosurface. The paleo-surface is slightly tilted to the $S W$ and river incision is deeper in the NE than in the $S W$, as a sign of surface uplift and bending.

The interpretation of the paleo-surface on the NE-SW profiles (Fig. 4) is constrained by i) the crossing with NW-SE profiles, ii) relative highs, and iii) presence of detrital fluvial sediments found in perched valleys. The interpreted paleo-surface shows a general southwestward tilt, opposite to the NE-flowing present-day Chassezac river. This paleosurface is cut by a more significant incision of La Baume and La Planche rivers $(>150$ $\mathrm{m})$ to the NE, than the Chassezac river $(<80 \mathrm{~m})$ to the SW (Fig. 4).

\section{Discussion}

The paleo-surface has been deeply incised by the Chassezac and La Baume rivers, as well as all their tributaries, in response to the lowering of the base-level. Consequently, the karstic network has sunk into the carbonate massif exposed at that time, or shortly after, depending on the rates of karstic incision. No evidence of epigene karstification below the present base- 
level has been found in the speleological record (Chabaud and Lhomme, 2016), which provides the lower boundary and vertical extension of the epigene karstic aquifer.

Datation of this paleo-surface is a key point of this study, but it is poorly constrained. However, it can be noted that: i) the downstream paleo-surface onlaps onto the tilted bloc of La Serre, formed during Oligocene rifting (Sanchis and Séranne, 2000), and ii) the river network belongs to the Rhône river drainage that flows to the Northwest Mediterranean, which was formed during the Oligocene-Aquitanian rifting of the Gulf of Lion (Séranne, 1999). This suggests that the paleo-surface was developed after Oligocene-Aquitanian rifting. The age of the paleo-surface abandonment must be discussed in the light of the origin of baselevel lowering. Surface abandonment, rivers incision and karstification could result from upstream regressive incision of the Ardèche river during the Messinian salinity crisis in the Mediterranean Sea, followed by the Pliocene transgression (Pliocene Rias, Fig 1a) well documented some $20 \mathrm{~km}$ downstream of the study area (Mocochain et al., 2006b). Alternatively, it could be related to the Late Miocene uplift (Serravalian-Tortonian) referenced in neighboring areas of Languedoc (Séranne et al., 2002). The NE-SW elevation profiles (Fig. 4) show a southwestward tilting of the paleo-surface and a long wave, low amplitude $( \pm 100 \mathrm{~m})$ up-warping in the eastern part of the study area. The observed increasing amount of incision in a downstream direction contradicts an upstream, regressive, erosional process, as expected in response to sea-level drop. Our observations favur a tectonic origin (uplift) rather than a base level lowering by desiccation of the Mediterranean Sea during Messinian. Finally, this provides the youngest boundary for the paleo-surface abandonment, which was form

ed after the Aquitanian and before the Serravalian-Tortonian.

\section{Conclusion}

As a result of the Oligocene-Aquitanian rifting of the Gulf of Lion, a fluvial drainage network was established, flowing towards the Mediterranean Sea, which led to the formation of an erosional/depositional paleo-surface in the Païolive area (Fig. 5a). During the Serravalian-Tortonian interval, a differential uplift lead to a long wave, low amplitude uplift and bending in the north-east of the study area. This event induced river network incision, abandonment of the paleo-surface, and karstic network sinking into the Late Jurassic carbonate massif (Fig. 5b). Such karstification therefore predates the canyon-incision of the lower reaches of the Ardèche and the related karst formation in the Ardèche plateau (Fig. 1a).

Such preliminary geological and geomorphological combined study sheds new light on the extend, genesis and chronology of an epigene karst, which bring constraints on its future hydrological modeling. 

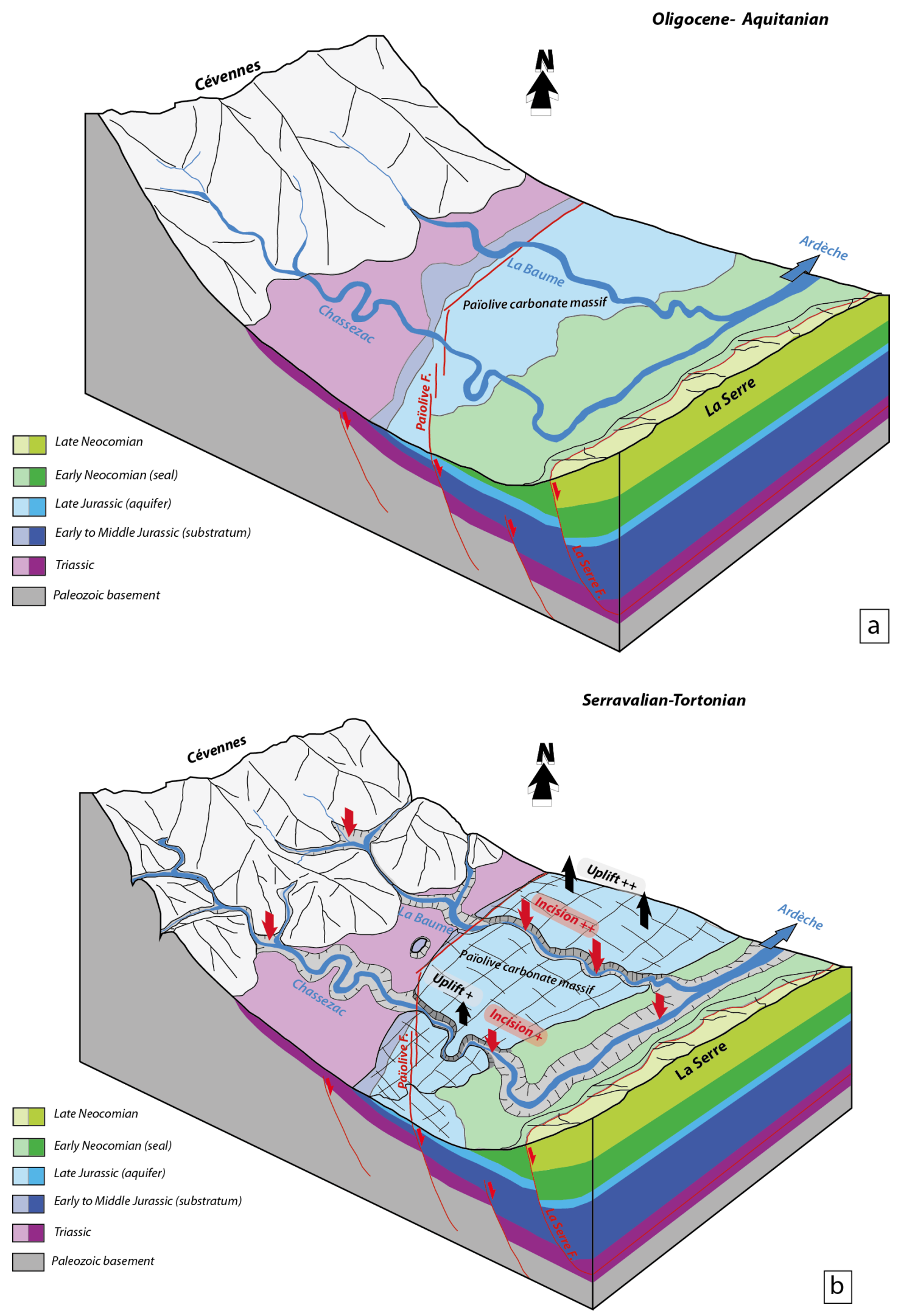

Fig. 2 : Schematic 3D diagrams illustrating the geological setting and the genesis of the Païolive karst. 5a: Oligocene - Lower to Middle Miocene : formation of a paleo-surface linking the Cévennes Paleozoic basement high to the La Serre tilted bloc. $5 \boldsymbol{b}$ : Late Miocene (pre-Messinian): differential uplift produced bending of the area, which induced abandonment of the paleo-surface, incision of the river network and karstification of the carbonate uplifted plateaus. 


\section{Acknowledgements}

We are thankful to the three anonymous referees who provided detailed and constructive reviews that helped improving this work. We are also grateful to Catherine Bertrand who invited this contribution and for her editorial work.

\section{References}

Bakalowicz, M., 2008, réflexions sur la genèse du karst du bois de Païolive: Les Cahiers de Païolive, v. 1, p. 87-94.

Bonijoly, D., Perrin, J., Roure, F., Bergerat, F., Courel, L., Elmi, S., Mignot, A., and GPFTeam, 1996, The Ardèche paleomeargin of the South-East Basin of France: mesozoic evolution of a part of the tethyan continental margin: Marine and Petroleum Geology, v. 13 , no. 6 , p. 607-623.

Chabaud, M., and Lhomme, M., 2016, Païolive souterrain: Cahiers de Païolive v. 2.

Clerc, C., 2009, Structure et fonctionnement du système karstique de Saint André de Cruzières [Master 2: Université Montpellier 2 - SupAgro Montpellier, 65 p.

Elmi, S., Brouder, P., Berger, G., Gras, H., Busnardo, R., Bérard, P., and Vautrelle, C., 1989, Carte Géologique de la France à 1/50000e Feuille de Bessèges - ${ }^{\circ}$ 888: BRGM.

Mocochain, L., Bigot, J.-Y., Clauzon, G., Faverjon, M., and Brunet, P., 2006a, La grotte de Saint-Marcel (Ardèche) : un référentiel pour l'évolution des endokarsts méditerranéens depuis 6Ma: Karstologia, v. 48, p. 33-50.

Mocochain, L., Clauzon, G., Bigot, J.-Y., and Brunet, P., 2006b, Geodynamic evolution of the peri-Mediterranean karst during the Messinian and the Pliocene: evidence from the Ardèche and Rhône Valley systems canyons, Southern France: Sedimentary Geology, v. 188-189, p. 219-233.

Sanchis, E., and Séranne, M., 2000, Structural style and tectonic evolution of a polyphase extensional basin of the Gulf of Lion passive margin: the Tertiary Alès Basin, southern France: Tectonophysics, v. 322, p. 243-264.

Séguret, M., Benedicto, A., and Séranne, M., Structure profonde du Gard Rhodanien, Apport $\mathrm{du}$ retraitement et de la réinterprétation de données sismique régionales, in Proceedings Journées Scientifiques ANDRA, Bagnols sur Cèze, 1997, Volume Atlas des Posters, ANDRA / CNRS, p. G.G.15.

Séranne, M., 1999, The Gulf of Lion continental margin (NW Mediterranean) revisited by IBS: an overview, in Durand, B., Jolivet, L., Horváth, F., and Séranne, M., eds., The Mediterranean Basins : Tertiary extension within the Alpine Orogen, Volume Special Publication 156: London, The Geological Society, p. 15-36.

Séranne, M., Camus, H., Lucazeau, F., Barbarand, J., and Quinif, Y., 2002, Surrection et érosion polyphasées de la bordure cévenole - Un exemple de morphogenèse lente: Bulletin de la Société Géologique de France, v. 173, no. 2, p. 97-112.

Tassy, A., Mocochain, L., Bellier, O., Bruacher, R., Gattacceca, J., and Bourlès, D., 2013, Coupling cosmogenic dating and magnetostratigraphy to constrain the chronological evolution of peri-Mediterranean karsts during the Messinian and the Pliocene; example of Ardeche Valley, southern France: Geomorphology, v. 189, p. 81-92.

Wheeler, H. E., 1964, Baselevel, lithosphere surface, and time-stratigraphy: Geological Society of America Bulletin, v. 75, no. 7, p. 500-609. 